\title{
STATE SPEECH FOR PERIPHERAL PUBLICS IN JAVA
}

\author{
Joseph Errington
}

Since the 1965 bloodbath which ended its failed experiment with constitutional democracy, Indonesia has been ruled by a highly centralized, military-dominated government which has moved unilaterally to modernize the country's economic infrastructure and indoctrinate Indonesians into the ways and sentiments of its own version of nationalism. This self-named New Order has quashed all opposition to its top-down implementation of policies which have, among other goals, the national integration of rural communities like those in south-central Java which I discuss here. ${ }^{1}$ A self-legitimizing modernist ideology has licensed the New Order's self-assumed right to oversee "development" (pembangunan) and "improvement" (pembinaan $)^{2}$ of the lot of Indonesia's vast, heterogeneous peasantry, and has underwritten as well the perceived superiority of state officials. "All Indonesians I have ever met," one outspoken Indonesian intellectual has commented, "feel that they are the subordinates (bawahan) of the government. Moreover there are very many of our officials in the regions or outlying areas who feel confident that they really are the superiors (atasan) of the people."

The Republic of Indonesia (Republik Indonesia) is no res publica, and harbors no such "public" as has been described, debated, or imagined in discussions following Jürgen Habermas' influential chronicle (1989) of the rise of civil society. Indonesia's founders, largely a Dutch educated intelligentsia and suborned ethnic elite, took over a colonial administrative infrastructure along with its administrative language, Malay, suitably renamed Indonesian. ${ }^{3}$ The social and technological prerequisites for any sort of "public sphere" hardly exist in Indonesia; the major weekly magazine in this country of roughly 190 million sold only 150,000 or so copies a week before its recent closing by the government; the nation's leading newspaper (over and against tabloid-style mass publications) sells about half a million copies a day. Marketing surveys show readers to be primarily university and high school graduates who live in urban areas and are employed as civil servants, managers, and other professionals.

\footnotetext{
${ }^{1}$ Research reported here was carried out in 1985-86 with help from the Social Science Research Council, the National Science Foundation, and the Wenner-Grenn Foundation. I am grateful for institutional support from the Lembaga Ilmu Pengetahuan Indonesia, or Indonesian Academy of Sciences, during that research. All opinions expressed here are my own.

${ }^{2}$ Unless indicated otherwise, foreign words cited in the body of the text are Indonesian, not Javanese.

${ }^{3}$ On this issue see Hoffman 1979 and sources cited here.
} 
The power of rigid, self-interested state oversight of public discourse is evident in the lack of explicit censorship laws and in statements like that of the Minister of Information in 1989, for instance, that no opposition to government policy exists or should exist in the Indonesian press. (See Heryanto 1990.) When self-censorship has failed to prevent transgression of unstated limits on content and tone of reportage, the New Order has not hesitated to peremptorily close and sometimes eradicate newspapers and magazines. Such was the case in 1994, for instance, when three news magazines, including the most widely circulated mentioned above, were summarily put out of business.

Indonesia has developed out of a colonial empire into a state-dominated polity which fits better C. Wright Mills' characterization of mass society. This label resonates, for instance, with the New Order's own name for its longstanding "floating mass" policy, which proscribes political activity in rural communities save during state established, state supervised election periods. The bulk of this citizenry forms a rural populace regarded by many elites as (to use a common, condescending phrase) 'still stupid' (masih bodoh). Such backward villagers have been accorded a collective status as recipients rather than active participants in policy formulation or implementation, which are wholly within the New Order's purview. For these and other reasons it is easy to view the New Order as a kind of security apparatus oriented primarily to political and economic interests of its elite and allies.

Whatever purchase such cynical, instrumentalist readings have on practice and policy of the New Order elite, they offer little insight into the ideas and sentiments of "ordinary citizens" engaged day-to-day with the many faces of modernity and nationalism. The dominant rhetoric of progress (kemajuan) and development (pembangunan) has real salience for many Indonesians' construal of, participation in, and resistance to massive, state-sponsored transformations of their lives, families, and communities. Peasants' engagements with superposed, centralizing policies are parts of complex responses to efforts to make them a peripheral, passive, yet self-perceivedly Indonesian public. As the state has progressively saturated villages and brought villagers under its political, economic, and educational aegis, it has likewise superposed the social identities and categories with which villagers are enabled and obliged to negotiate their relations with the state and each other in a new national polity.

I consider such massive change here through two transient but concrete points of contact between state and villagers, bits of events in which state officials addressed peripheral, public audiences. "Public" serves here as a rubric for the events created and speech used when Javanese villagers are convened at state behest to listen to talk by state representatives about state concerns. Before, after, and (perhaps) during these events they are co-members of a local community, bound together by shared social biographies. But the goals, topics, and institutional logic of such "public" events presuppose their temporary coparticipation as a gathered fraction of their nation's citizenry. Even as passive participants, villagers then accede to an impersonal, superposed status which is mapped at least temporarily onto local community gatherings.

Officials publicly mediate these relations through genres of public talk, Javanese and Indonesian, which I discuss in this paper with recourse to transcripts of tiny bits of two such events. I consider ways in which Javanese speech genres serve to mitigate the state's institutional presence at such events, and simultaneously 
to create useful ambiguities in the "publicness" of those gatherings. To explore the ethnic and national inflections of this double-sided engagement, I focus on speakers' capacities as mediators between an audience and the authority which they assume and implement. By contrasting Javanese or Indonesian modes of authoritative speakership, sponsorship, and audiencehood, I try to develop a sense of the genres of public speech which subserve public speakership, and reciprocally shape collective roles of public audiences.

Javanese language commonly serves Indonesian officials, in Indonesian venues, to speak about Indonesian topics. This may on the face of things be surprising. Indonesian - devoid of ethnic inflection, strongly and transparently backed by the state, redolent of state ideology in public use - would seem institutionally normative for speech by state agents, at state-sponsored gatherings, about state business, to state citizens. But bilingual Javanese Indonesian officials commonly do Indonesia's public business in Javanese, as in the event from which is drawn the talk transcribed in text 1. Here the administrative head of a mountainous, eastern subdistrict of south-central Java deals with very Indonesian administrative and fiscal matters at an ostensibly Indonesian gathering called a rapat desa 'subdistrict meeting'. Several hundred residents and citizens of the district he supervises were gathered outside his office to listen to him speak through a loudspeaker at this event.

\section{Text 1: Rapat desa/Village meeting}

\footnotetext{
Panjenenganipun párá bapak-bapak. Bilih ing sakmangké kulá badhé ngaturaken wontenipun keuangan desa ing tahun anggaran séwu sangang atus wolungdásá gangsal, séwu wolung atus, séwu sangang atus wolung dásá nem ingkang kawiwitan wulan April tahun wolungdásá gangsal dumugi ing wulan Maret tahun wolungdásá nem.

Sadèrèngipun kulá ngaturaken wontenipun lapuran kula salebelipun setunggal tahun, ing samangké mbok bilih anggènipun ngaturaken sáhá nglapuraken wontenipun keuangan desa salebetipun setunggal tahun dhumateng párá bapak-bapak sedáyá, mbok menawi wonten kekiranganipun. Kula nyuwun pangapunten awit bilih sadèrèngipun kula lapuraken, wonten ingkang kedah mlebet soal keuangan desa, nanging dèrèng saged mlebet, dados janipun sampun setor dhumateng désa, nanging kabektá dèrèng cethá, pramilá ing samangké nyuwun pangapunten dhumateng párá bapak-bapak ... .
}

[1] Honored gentleman.

Now I will present the village fiscal situation in budgetary year one thousand nine hundred

[5] eighty five, one thousand eight hundred, one thousand nine hundred eighty six, which begins the month of April, year eighty-five through the month of March, the year of eighty-six.

[10] Before I present my report for the single year, at present perhaps [my] presentation and reporting of the village fiscal situation in the year

[15] to all you gentlemen, perhaps there will be shortcomings. I beg forgiveness so that before I report, there are [moneys] which should be entered village finances,

[20] but can't yet enter, so actually they're deposited to the village, but [as they] are not yet clear, therefore at present [I] beg forgiveness to the gathered gentlemen...

Such usage provides convenient prima facie evidence of how little of the emerging relation between Indonesian and Javanese can be captured with bifurcate diglossic oppositions between high and low, formal and informal, or public and 
private languages (see Errington 1991 for discussion of the relevant literature.) It shows, rather, the need to consider Javanese as an ensemble of speech styles, some of which can be performatively figured against an Indonesian institutional ground like this rapat desa: An event convened for governmental purposes, where the head administrator of a subdistrict discusses current fiscal matters.

Neither this brief segment or the lengthy speech from which it is drawn contains much Indonesian verbiage beyond a few technical phrases - keuangan desa 'village finances' and tahun anggaran 'budgetary year' - for which no plausible Javanese equivalents exist. Otherwise the speech is replete with diacritics of the formal variety of the Javanese speech style often called krama in the scholarly literature, and more often básá (or básá alus, lit., 'refined básá') by Javanese themselves. ${ }^{4}$ Such distinctively formal Javanese is normatively heard at ceremonies such as weddings, where it serves delegated, prototypically male masters of ceremonies to address gathered guests and announce events on behalf of a sponsoring host.

I call this style of Javanese "exemplary" here to signal two ways in which I try to relocate this transcription in my description of its originary context. The first, taken up in the next section, has to do with traditional Javanese geosocial and linguistic hierarchies tacitly invocable with such speech. The second involves relations between those who engage in "public" speech and sanctioning persons or institutions whose authority they then manifest yet dissimulate. Together, these paired themes help suggest how ethnic and national modes of authority and speech genres might converge and diverge in Indonesian yet Javanese public venues.

\section{Exemplary speech and speakers}

By recalling the notion of "exemplary center," the phrase "exemplary speech" helps thematize longstanding links between the social dialectal significances of the speech genre in text 1 and geosocial hierarchies in precolonial Central Java. A common theme in literature on Southeast Asian statecraft (see e.g. Anderson 1972; Geertz 1980; Tambiah 1976, 1985), is the place of exemplary centers as geopolitical and symbolic foci in precolonial kingdoms. So too the Central Javanese kingdoms of Jogjakarta and Surakarta, sustained and molded under Dutch aegis through the beginning of World War $\mathrm{II}{ }^{5}$ focussed on kings, courts, and cities which defined geographic centers and pinnacles of political and cultural hierarchies.

Exemplary language was the most elegant of the well-known Javanese speech styles, paradigmatically associated with the courtly circles of those cities to which its use was largely restricted. Use of such speech could be highly polite in face-to-face interaction, and mark a speaker's formal or deferential relation to a speech partner. But because knowledge of this style could only be acquired in these closed elite circles, its use could also be salient as a linguistic diacritic of speaker's high status. The longstanding association of elegant language with elite circles of exemplary

\footnotetext{
${ }^{4}$ For discussion see Errington 1985, 1988, and sources cited there.

${ }^{5}$ See on the politics and culture of this relation Pemberton 1989.
} 
centers enhanced the aura of refinedness accruing to such speech, and its speakers. Exemplary usage could be perceived, then, as a quasi-natural attribute of elitehood, what Habermas has called "a status attribute" through which a noble personage "displayed himself [sic], presented himself as embodiment of some sort of 'higher' power." (1989: 7) Recognized (or misrecognized) not as evidence of training in linguistic technique but perceptible index of imperceptible, intrinsically refined nature, exemplary Javanese was distinctive of what Bourdieu (1984) calls an "aristocracy of culture" and its speaker's character.

This association of exemplary language and geosocial class has long shaped geosocially variable understandings of the significances of exemplary usage like that in transcript 1 . Though this refined style can still occasionally be heard in everyday conversation among city elites, it has been largely displaced by Indonesian or less polished styles of Javanese for many speakers and in many contexts. (See Errington 1985.) But in villages relatively distant from those cities, like that in which the speech in transcription 1 was recorded, exemplary Javanese has long served primarily as mode of address on public occasions to gathered groups. This circumstance correlates with the fact that active command of such exemplary Javanese in rural areas has long been the province and verbal mark of local elite representatives of the exemplary center (See Errington 1991). Villagers then counted as members of audiences for address by socially privileged speakers, whose showing forth of exemplariness simultaneously legitimized the public event at which they spoke and their own spokespersonship. Such refined conduct could then be admired by a silent audience whose members recognized the distinctive worth of exemplary language but, by the same token, the unfittingness of any attempt on their own part to use it.

As doubly passive participants in use of language they neither speak nor are able to speak, villagers then accede to an asymmetric collective role which is not exchangeable for that of exemplary speaker. The exemplariness of this speech genre as a mode of "public" speech is underwritten by a prenational, patrimonial ethnic hierarchy, which stands in sharp contrast to the legitimacy of standard Indonesian. Constructed and disseminated as standard rather than exemplary language, Indonesian is putatively omniavailable to citizens by the state, ostensibly uninflected for ethnicity or class, and so backed by the ideology (if not practice) of Indonesian democracy. In this respect Indonesian's ostensible non-exclusivity as a vehicle of speech to a national public stands in tacit but clear contrast to traditionally exemplary Javanese speech and speakers.

\section{Exemplary speakers and sponsors}

This genre of Javanese can also be called "exemplary" in relation to modes of sponsorship for acts of exemplary speech, and the perceived nature of those who license and whose interests are then mediated in exemplary fashion. Exemplary speakers at traditional Javanese gatherings normatively spoke as intermediaries for sponsors whose tacit presence and authority was figured in ways resonant with broader understandings of power-laden relations between the sources and surrogates of power in exemplary centers.

A common theme in literature on Javanese statecraft (e.g. Anderson 1972) 
is power's efficacy, which emanates from exemplary centers and persons independently of their own overt action or direct involvement. A (normatively male) person's power to control his environment and other persons, by this logic, is evident mediately rather than through directly perceptible actions: The presence of power is deducible from its effects, including the actions of a powerful persons' delegates. Centers of potency are, as it were, evident in their absence, prototypically, in the persons of kings who oversee and exercise their will invisibly and mediately from the detached seclusion of their palaces. Ward Keeler has described in similar terms the "dissembled control" (1987: 163) which is exercised by sponsors of ritual events. Their potency is indirectly manifested not just by the coming together of individuals to form an audience, but also by the "sponsor's voice": A spokesperson who simultaneously represents the interests and dissimulates the involvement of a sponsor. By dissembling their involvement, sponsors manifest a capacity to attract an audience which lends gravity to the sponsored event, but counts also as an effect and index of sponsor's potency. This "dissimulation of exertion" (Keeler 1987: 141) lends such events significance as forms of status display, which presuppose that the work of talk be delegated to an exemplary speaker, who acts as sponsor's surrogate to a gathered audience.

In this way public, exemplary speech does not just set off the person of an exemplary speaker; it also underwrites that speaker's role as ventriloquator of interests and sentiments of a sponsor, a legitimizing entity whose silent authority a speaker manifests and mediates. Ostensibly powerful figures dissimulate their authority as what Goffman (1974) might call dissociated but not disinterested principals, and are complementarily represented by exemplary animators whom they sanction. Public exemplary speech can defer and refer to that authority, disclosing it by dissimulating its presence.

Exemplary Javanese talk like that transcribed in text 1 can be construed as imputing broadly similar forms of authority to the sponsor of this ostensibly Indonesian event, a silent, anonymous sponsor which is more powerful than its Javanese precursor: The Indonesian state. Potency's dissimulated, anonymous character in this respect permits the transposition of exemplary speech into a modern "public" venue, and the adoption of a guise of traditional authority by a different, "public" sponsor. Exemplary Javanese in Indonesian events helps in this way to blur differences between forms of authority and public speakership, allowing a minor bureaucrat to localize his privilege of public speech and the privileging power of the state he subserves.

Such a double interpretation of official, public uses of exemplary Javanese can be specifically as well as broadly apposite. In the talk beginning at line 15 in text 1 , for instance, this duly appointed subdistrict official completes a preface to his review of the district's finances. He is at pains to note a lag in bookkeeping which is beyond his control and prevents him from a full and accurate presenting of monthly figures. By dwelling on what is, in the larger scheme of things, a minor accounting problem, he shows himself a punctilious keeper of books and worthy functionary in the administrative framework within which such matters have significance. But in exemplary Javanese, he is able to punctuate these prefatory remarks with the quintessentially Javanese act of 'begging forgiveness,' uttering nyuwun pangapunten (at line 23). This does not just signal regret at a state of official affairs; it involves an act and stance typically adopted by exemplary speakers 
at Javanese gatherings. This phrase is a virtually obligatory signal of speaker's (and sponsor's) sensitivity to the needs of gathered others, and to the possibility of his own shortcomings. At the same time, it dissimulates a humble lack of expectations or investment in a "perfect" event, which one nonetheless hopes will come off as flawlessly as the speech itself.

Insofar as such an utterance invokes the feel of Javanese exemplary speech, speakership, and "public" events, it can also invoke the absent, sponsoring power of the state which this official duly represents, and which underwrites the event where his audience is duly assembled. This elegant phrasing simultaneously allows self-figuring as a conscientious yet exemplary representative of that potent sponsor. If exemplary qualities indirectly legitimize the official's privilege, they help legitimize the authority he mediates not just overtly by an ideology of modernist nationalism, but covertly through a received logic of speakership, sponsorship, and authority.

\section{Audiences, local and national}

If exemplary Javanese speech genres can supplement rather than subvert state authority, then such public events can accomplish a noteworthy symbiosis between state interests and institutions on one hand, and local understandings of "the public" among Javanese Indonesians on the other. Such events can assimilate Indonesian publicness into received understandings of hierarchy and conduct, and dissimulate Indonesian authority in local forms and terms. To these linked convergencies between speech and authority must be added a parallel doubleness or ambiguity in the nature of the "publics" so addressed, that is, the nature of the copresence assumed and created by its silent coparticipants.

Copresent persons addressed with exemplary speech in traditional rural venues are largely bound together before, after, and during public events as kin, neighbors, and acquaintances; they are members of what Alfred Schutz calls "a community of space and time" (1967: 163) which allows direct, mutual experience through more or less enduring, more or less dense networks of interaction. As such persons "grow older together" (1967: 165) they are for each other what Schutz calls consociates: Persons with overlapping, resonating, sometimes conflicting lifeworlds. In this respect public speech can represent a single, ceremonialized moment in an ongoing, collective social biography.

But the consociateship of such gemeinschaft differs greatly from the kinds of national imaginings which, as Anderson (1991) has argued, engender senses of community among anonymous co-citizens of nations. Such anonymous, typified others count as what Schutz would call contemporaries (1967: 176), who occupy the national space delimited, controlled, and rendered homogenous by a state system like the New Order. The New Order has worked effectively to homogenize politics and culture among its hugely diverse ethnic groups by reconstituting ethnicity in an Indonesian space, and supplanting it with a version of what Anderson calls official nationalism. By singling out, assembling, and juxtaposing particular diacritics of ethnic difference, the state has reframed "Javaneseness" (among others) in its own custodial terms and political interests.

This translocal framing of ethnicity differs from yet engages with understandings of togetherness among Javanese villagers who make up audiences 
for Indonesian officials. Exemplary Javanese speech can mute the felt relevance of abstract citizenship, as it mutes the relevance of the translocal national language. On one hand, topic, venue, and speaker's official status self-evidently signal the shared status of residents of an administrative district and citizens of the nation. "Public" use of exemplary Javanese, on the other hand, resonates with the local, nonnational sphere of social life within which persons know copresent others not as co-citizens but consociates. In this respect exemplary Javanese speech genres can help localize modern governmentality, and Javanize exogenous forms of authority.

\section{Bureaucratic Javanese?}

Exemplary Javanese, I have argued, affords a way of performatively figuring selfevidently personal exemplariness, and mitigating the official character of state oversight of villagers' lives. In silent, sanctioning absence lies the possibility of state power being temporarily and publicly figured in local Javanese terms, and of state legitimacy being embedded in a traditional logic of power relations. But this is no seamless grafting of ethnic onto national forms of speech in a reinvented style of New Order authority. Smooth or not, this social transition is grounded and given impetus by the New Order's distinct interests and dominant governmentality, for which Indonesian is the efficient, uniform, superordinate language. The public use of exemplary Javanese is in this respect tacitly circumscribed by the state's purposes; when those purposes do not lend themselves to dissimulation, state functionaries are obliged to represent the state more transparently. Differences in the authoritativeness of standard Indonesian and exemplary Javanese can then refract in stylistically and socially dissonant acts of public speech.

Occupants of niches in the bureaucracy now superposed on local communities are ultimately responsible to the state as the implementers of rules and decisions conveyed through its official hierarchies. Their dependence on this hierarchy, and subservience to their administrative superiors, may be clearest when they must function as local conduits for state information and directives. To act publicly in such transparently mediating capacities requires a mode of talk which is correspondingly transparent with both content and genre of official information, which is written and (ostensibly) disseminated uniformly across national space. That
medium is Indonesian.

Such duties can impinge, then, on local enactments of authority, and engender the kinds of generic and social tension which appear in text 2 . This is taken from a meeting in which the state comes into its most local contact with a very tiny segment of its peripheral, partially illiterate populace. This is a meeting of male heads of households of one of the state's smallest administrative units, the neighborhood of forty or so households called the rukun tetangga, or $R T$ (pronounced er te). (Indonesian segments are italicized; Javanese are not.) The speaker is the official head of this unit, a kind of primus inter pares known and addressed as Pak RT (roughly, 'Father RT'). He meets every two weeks or so as with members of this government sponsored group called by the Indonesian acronym Kelompencapir. This is an acronym for Kelompok pendengar, pembaca, dan pirsawan, which can be glossed briefly as 'group of readers, listeners, and watchers', i.e., consumers of the (state sponsored, state supervised) mass media. 
These are also convenient venues, by no coincidence, for doing local state business and mediating relations between subdistrict heads (like the lurah who provided text 1) and neighborhood groups. This $R T$ normally addresses his audience in exemplary Javanese, but at this point in this meeting finds himself obliged to animate a directive issued by Indonesian authorities, in Indonesian words. His effort to effect a transition between his statuses, speaking roles, and relations to his audience is not entirely successful, and gives rise to generic tensions which are symptomatic of ambiguities and tensions implicit in use of exemplary Javanese to a peripheral Indonesian public.

Pak $R T$ has reached a point in the meeting - otherwise entirely in formal if not entirely exemplary Javanese - where he notifies his audience of new regulations which have come from the ministry of the interior concerning requirements for prospective local officials. That he presumes at least passive knowledge of Indonesian is clear from the fact that he reads but does not translate these regulations save for the word underpol, (lines 16-17), which means something like 'accomplice' and is in fact extremely rare. But he is concerned to frame this considerable Indonesian verbiage, (italicized in the text) within a sustained Javanese discourse, interpolating core Indonesian phrases and words into speech otherwise marked as generically

\section{Text 2. Kelompencapir/ The reading, listening, and watching group}

Déné syarat-syaratipun mangkédados ketua sâhá pengurus èr té menika: setunggal, nggih meniká ingkang bertakwa terhadap Tuhan yang maha ésa, nggih meniká setunggal. Bab tugas kepengurusan, setunggal inggih meniká bertaqwa terhadap Tuhan yang maha ésa. Kaping kalih nggih meniká, setia sáhá taat kepada Pancasila sáhá undang-undang dasar empat puluh lima. Kaping tigá nggih meniká setia sáhá taat kepada negara dan pemerintah. Sekawan nggih meniká berkelakuan baik, jujur, adil, cerdas dan berwibawa. Lajeng E: tidak pernah terlibat langsung atau tidak langsung wontenipun pengaruh gerakan Gé tiga puluh S/PKI, sáhá underpolipun, underpol meniká bawahannya dari pada Pé Ka I. Ef: tidak dicabut hak pilihnya berdasarkan keputusan pengadilan. Dados hak pilihipun tidak dicabut. gé: nggih meniká sehat jasmani lan rochaninipun. Ha: dapat membaca dan menulis aksárá latin. I: telah bertempat tinggal tetap sekurang-kurangnya nam bulan dengan tidak terputus-putus. Menika syarat-syaratipun. Dados bertempat wonten
[1] As for the requirements to become head and supervisor of the neighborhood: first, that is devotion to God Almighty, that is

[5] first. As for duties of administration, one is devotion to God the Almighty. Number two, that is, faithful and observant of Pancasila and the constitution of forty-

[10] five. Third, that is faithful and loyal to nation and government. Four, that is good conduct, fair, just, clever and authoritative. Then E: never involved directly or

[15] indirectly in the influence of the movement of $G$ thirty $S / \mathrm{PKI}^{6}$ or their underpol, "underpol" are subordinates of the PKI. F: the right to vote has not been taken away on the basis of a court

[20] verdict. So the voting rights haven't been taken. G: This is healthy in body and the mind. $\mathrm{H}$ : can read and write Latin letters. I: have lived permanently at least six

[25] months without interruption. Those are the requirements. So residing here [means]

\footnotetext{
${ }^{6} \mathrm{PKI}$ is an acronym for Partai Komunis Indonesia, the Indonesian Party eradicated by the army in 1965.
} 
mriki sedikitnya enam bulan tidak terputusputus. Lajeng yang dapat ditunjuk menjadi pengurus rukun tetangga seluruhipun warga sebagai yang dimaksud maksud ayat satu dan dua adalah penduduk setempat warga negara terdapat terdaftar pada kartu keluarga. Pokokipun meniká ingkeng saged dados inggih meniká penduduk asli, nggih meniká penduduk ingkang sampun kagungan $\mathrm{Ka} \mathrm{Ka}$, Kartu Keluarga kados kálá mbèn meniká. Meniká párá sedhèrèk syarat-syaratipun. Mbok menawi mbenjing mangké utawi mbenjing badhé ngleksanakaken pemilihan meniká kedah memenuhi syarat menika, awit meniká dipun, a, dipunsahkan saking mentri dalam negeri. at least six months continuously. So those who can be designated neighborhood heads all of them

[30] are members as meant by, the intent of stipulations one and two are local residents, citizens found listed on the family register. The main thing is, those who can are

[35] native residents, that is residents who have a $K a \mathrm{Ka}$, family register, like before. Those, siblings, are the requirements. Perhaps another day later or in the future

[40] will be carried out an election, [candidates] must meet these requirements, because these have been, uh, have been officialized by the minister of the interior.

Javanese by a variety of grammatical and syntactic markers. At line 20, for instance, he reads directly regulation $\mathrm{F}$ - tidak dicabut hak pilihnya berdasarkan keputusan pengadilan - without a Javanese gloss, but does repeat the two key phrases (hak pilih- 'voting rights' and tidak dicabut 'not withdrawn') within an utterance otherwise marked as exemplary Javanese (by Dados 'so, thus' and -ipun 'genitive marker').

$P a k R T$ ventriloquates official Indonesian words by imbricating them into the fabric of "his own" Javanese speech, but in so doing creates a momentary stylistic awkwardness. This could be traced, along lines suggested by Bakhtin (1981) to the monologic nature of discursive authority: Two such ostensibly authoritative modes of discourse are forced here into a heteroglot, dissonant juxtaposition. That dissonance indexes the broader lack of fit between the state's translocal business, and mutualistic expectations of locally gathered consociates. Pak RT here attempts to maintain a double relation to the text he is reading. As faithful mediator between state and citizens, he tries to mitigate social differences by juxtaposing their differentially appropriate genres. He works to domesticate the state's business by setting off a temporarily unmuted officialness from his otherwise exemplary talk as co-ethnic neighbor.

\section{Conclusion}

Such institutional, generic, performative tensions appear as tiny, transient wrinkles in the social fabric of Indonesian Javanese public talk, but they bespeak a broader, underlying accommodation between the malleable political culture of prenational Central Java and the Indonesian state's ideology and interests. This might be less convergence than transient reflex of rapid change from prenational Javanese polity to postcolonial nation-state, and so from what Jürgen Habermas might call the absolutist public sphere of an exemplary center to Mills' state-dominated mass society. Such an argument would have much in common with neotraditional readings of political and cultural change in Indonesian, and can be reinforced by the obvious, nontrivial observation that the Indonesian state apparatus is dominated by a new Javanese elite which has done much to assimilate a particular version of Javanese 
tradition into a new Indonesian high public culture. ${ }^{7}$

To situate (transcripts of) tiny bits of talk against the backdrop of complex social transitions which they transiently subserve, I have had recourse to a notion of "public" not as sphere of neutral discourse by and among coequal citizens, but in the more theatrical sense of audience, gathered for performances sponsored and performed by authoritative Javanese Indonesian speakers. I have tried to use it as a rubric for construing the extension and implementation of state power at some of its peripheries. Talk to such peripheral publics may disguise or dissemble differences between modes of speakership, sponsoring authority, and copresence among covillagers who must partake of citizenship in the nation-state. New kinds of public, exemplary Javanese may help reproduce and modify hierarchical relations, and subserve a broader transition to Indonesian genres of public talk. And with these shifts, perhaps, will emerge genuinely new modes of public citizenship, modalities of public speakership, and, perhaps, of public political action.

\section{A note on transcription:}

Standard Indonesian orthography is used; consonant symbols have values close to their English equivalents save that /ng/ represents a velar nasal. Vowels have roughly the following values: $/ i /$ as in "she," $/ u /$ as in "shoe," /e/ as in the first part of the diphthong in "shade," /o/ as in the first part of the diphthong in "shoal," $/ a /$ as in "shot." Epenthetic glottal stops between vowels are not transcribed. With a few exceptions, Javanese words are transcribed with the same orthography: /dh/ represents a postalveolar dental stop, over and against dental $/ d /$; $/ a /$ represents a low, back, semi-rounded vowel somewhat like that in "shore;" / $/ \ell / / \ell /$, and $/ e /$ contrast as do roughly the vowels in "shade," "shed," and the last syllable of "sofa."

\section{References}

Anderson, B.R.O'G. (1966) The languages of Indonesian politics. Indonesia 1:89-116. Reprinted in Anderson 1990.

Anderson, B.R.O'G. (1972) The idea of power in Javanese culture. In C. Holt, B. Anderson, \& J. Siegel (eds.), Culture and politics in Indonesia. Ithaca: Cornell University Press, 1-69.

Anderson, B.R.O'G. (1990) Language and power: Exploring political cultures in Indonesia. Ithaca: Cornell University Press.

Anderson, B.R.O'G. (1991) Imagined communities, London: Verso.

Bakhtin, M. (1981) Discourse in the novel. In M. Holquist (ed.), The dialogic imagination. Austin: University of Texas Press.

\footnotetext{
${ }^{7}$ On this generall process see Pemberton 1989; for a discussion of the complementary politics of Javanese and Indonesian language among that national elite see Errington (forthcoming) and the literature cited therein.
} 
Bourdieu, P. (1984) Distinction: A social critique of the judgement of taste. trans. R. Nice. Cambridge, MA: Harvard University Press.

Budiman, A. (ed.) (1990) State and civil society in Indonesia. Clayton, Australia: Center of Southeast Asian Studies, Monash University.

Errington, J. Forthcoming. Indonesian('s) authority. In Paul Kroskrity (ed.), Language and Ideologies.

Errington, J. (1992) On the ideology of Indonesian language development. Pragmatics 2:3.417-427.

Errington, J. (1991) A muddle for the model: Diglossia and the case of Javanese. Southwestern Journal of Linguistics: Special issue on diglossia 10:1.189-213.

Errington, J. (1988) Structure and style in Javanese: A semiotic view of linguistic etiquette. Conduct and Communication Series. Philadelphia: University of Pennsylvania Press.

Errington, J. (1985) Language and social change in Java: Linguistic reflexes of social change in a traditional royal polity. Monographs in International Studies. Southeast Asia Series no. 65. Athens, $\mathrm{OH}$ : Ohio University Center for International Studies.

Geertz, C. (1980) Negara. Princeton: Princeton University Press.

Goffman, E. (1974) Frame analysis. New York: Harper and Row.

Habermas, J. (1989) Structural transformation of the public sphere, trans. T. McCarthy. Cambridge, MA: MIT Press.

Heryanto, A. (1990) State ideology and civil discourse. In A. Budiman (ed.), State and civil society in Indonesia. Clayton, Australia: Center of Southeast Asian Studies, Monash University, 289-300.

Hoffman, J. (1979) A foreign investment: Indies Malay to 1901. Indonesia 27:65-92.

Keeler, W. (1987) Javanese shadow plays, Javanese selves. Princeton, NJ: Princeton University Press.

Pemberton, J. (1989) The appearance of order: A politics of culture in colonial and postcolonial Java. $\mathrm{Ph}$.D. dissertation, Cornell University.

Schutz, A. (1967) The phenomenology of the social world. Evanston, IL: Northwestern University Press.

Tambiah, S. (1976) World conqueror and world renouncer. Cambridge: Cambridge University Press.

Tambiah, S. (1985) The galactic polity. In Culture, thought, and social action. Cambridge, MA: Harvard University Press. 